\title{
Induction of Interferon-Gamma (IFN- $\gamma$ ) and T Helper 1 (Th1) Immune Response by Bitter Gourd Extract
}

\author{
Kazunori IKE ${ }^{1)}$, Yuko UCHIDA ${ }^{1)}$, Tomohiko NAKAMURA ${ }^{1)}$ and Soichi IMAI ${ }^{1)}$ \\ ${ }^{1)}$ Department of Veterinary Parasitology, Nippon Veterinary and Animal Science University, Musashino, Tokyo 180-8602, Japan
}

(Received 21 October 2004/Accepted 24 January 2005)

\begin{abstract}
Mice were inoculated intraperitoneally wih 34 different types of vegetable juices, and interferon-gamma (IFN- $\gamma$ ) and interleukin-4 (IL-4) were measured as markers for the induction of Th1 and Th2 cells, respectively. Serum IFN- $\gamma$ level was markedly increased in mice inoculated with bitter gourd (Momordica charantia) juice, but IL-4 levels were not increased with any of the 34 vegetable juices. Testing of the various components of bitter gourd, including peel, pulp, and seed, showed that the pulp induced the highest levels of IFN- $\gamma$. Trial immunogen including the heat extract of the pulp induced specific $\operatorname{IgG}_{2 \mathrm{a}}$ antibody of the mice serum inoculated with this immunogen. These results demonstrate that bitter gourd pulp induced IFN- $\gamma$ production and show its promise as a means of effective immunostimulatory therapy specific for Th1 cells and IFN- $\gamma$ production.
\end{abstract}

KEY WORDS: bitter gourd, interferon-gamma, Th1.

Immune function in mammals is a complex and important homeostasis mechanism involving a variety of white blood cells, such as B cells, T cells, natural killer (NK) cells, and phagocytes (macrophages and neutrophils). Recent studies have shown the importance of the balance of $\mathrm{T}$ helper 1 (Th1) and T helper 2 (Th2) cells in the host immune response to infection $[11,14,15]$. Normal mice usually have low susceptibility to Neospora caninum, but the interferon-gamma (IFN- $\gamma$ ) knockout mouse and the anti-IFN- $\gamma$ antibody treated mouse are highly susceptible to infection with $N$. caninum $[4,7]$. This protozoa is an intracellular parasite, so in addition to humoral immunity mediated by antibodies and complement, activation of Th1 cellular immunity, primarily involving macrophages and neutrophils, is also important [1]. To prevent these types of intracellular parasitic infections, vaccines using parasite antigens or recombinant parasite antigens have been developed. However, these vaccines with only antigens are often insufficiently effective, so supplemental immune therapy with substances capable of inducing Th1 cellular immunity is necessary [5].

Plant derived substances are often recognized as highly "foreign" by the host immune system. In other words, plant derived substances, by virtue of local accumulation and increase in immune cells, can have immunostimulatory effects [10]. In addition to parasite derived antigens in vaccines to control intracellular parasites, the use of immunostimulatory substances to control Th1 or Th2 cellular responses can dramatically increase the effectiveness of these vaccines.

Therefore, we have focused on finding plant substances, particularly those of vegetables, capable of non-specifically inducing Th1 and Th2 cells.

Experimental animals, 5-week-old female ddY mice, were purchased from Saitama Experimental Animal Supply Co. (Saitama, Japan).
For the preparation of Propionibacterium acnes suspension, $P$. acnes was incubated in brain heart infusion broth (containing $0.03 \%$ L-cysteine and $0.03 \%$ Tween 80 ) (Difco, U.S.A.) by stationary culture at $37^{\circ} \mathrm{C}$ for $24 \mathrm{hr}$. After incubation, the bacterial suspension was centrifuged $(5,900 \mathrm{~g}, 20$ $\min$ ) and resuspended in $0.01 \mathrm{M}$ phosphate buffered saline, $\mathrm{pH}$ 7.2, (PBS). The $P$. acnes suspension was inactivated by heating for $30 \mathrm{~min}$ at $60^{\circ} \mathrm{C}$ and then stored at $4^{\circ} \mathrm{C}$ until the use.

For inoculation of the mice with $P$. acnes suspension and blood sample collection, each mouse was inoculated intraperitoneally with $0.5 \mathrm{~m} l$ of $P$. acnes suspension $(1 \mathrm{mg} / \mathrm{m} l)$. At $0,2,4,6,8$, and 10 days after inoculation, blood was collected from the hearts of 3 animals.

In this study, 34 vegetables were used: eggplant, green pepper, tomato, pumpkin, watermelon, ginger, carrot, Japanese radish, turnip, lotus root, burdock, Irish potato, garlic, onion, green onion, leek, cabbage, komatsuna, Napa cabbage, lettuce, broccoli, cauliflower, Malabar spinach, Angelica, Jew's mallow, parsley, Japanese ginger, water shield, celery, bitter gourd, gumbo, spinach, yam, and taro. Each vegetable was pulped with a mixer, and the stock solutions were prepared by adding $2 \mathrm{~m} l$ of sterile distilled water to $1 \mathrm{~g}$ (final weight) of each vegetable. For some vegetables, higher dilution solutions were also prepared.

The bitter gourd was separated into peel, pulp, and seeds. Each was dried by incubation at $25^{\circ} \mathrm{C}$ for $24 \mathrm{hr}$, followed by resuspension in sterile distilled water for injection $(1,000$ $\mathrm{mg} / \mathrm{m} l$ as $\times 1)$.

Three mice were inoculated intraperitoneally with $0.5 \mathrm{ml}$ of one type of vegetable juice prepared as above. A control group of mice was similarly inoculated with $0.5 \mathrm{~m} l$ of PBS. Seven days after inoculation, whole blood was collected from the heart of each animal. Blood counts were measured and the remaining serum was separated and stored at $-80^{\circ} \mathrm{C}$ until use. 
Blood samples from mice inoculated with vegetable juice were immediately anticoagulated with heparin. Leukocytes were counted with a fully automated blood cell counter (Celltac alpha; Nihon Kohden Co., Tokyo, Japan).

Cytokines measured in the blood samples from the mice inoculated with $P$. acnes and each vegetable juice included IFN- $\gamma$, as a marker of Th1 cells, and interleukin-4 (IL-4), as a marker of Th2 cells. The assays were performed using mouse IFN- $\gamma$ and mouse IL-4 ELISA kits (Endogen, U.S.A.) according to the manuals provided with the kits.

For the effect of extract of bitter gourd pulp on the immunization in mice, dried bitter gourd pulp was added to distilled water at a concentration of $20 \mathrm{mg} / \mathrm{m} l$, and homogenized using an ART-MICCRA D-8 homogenizer at setting $\mathrm{C}$ for $5 \mathrm{~min}$. The homogenate was heated at $100^{\circ} \mathrm{C}$ for $1 \mathrm{hr}$ and centrifuged at $12,000 \mathrm{~g}$ for $30 \mathrm{~min}$. The supernatant was filtrated using a $0.45-\mu \mathrm{m}$ pore size Millex-HV filter (Millipore, U.S.A.) and used as heat extract of bitter gourd pulp (HEBGP).

For the preparation of two immunogens including $N$. caninum tachyzoite surface Nc-p43 recombinant antigen (rNc-p43), the method of Son et al. [17] was used as follows: $10 \mathrm{~g}$ squalane (Wako Pure Chemical Industries, Ltd., Osaka), $4 \mathrm{~g}$ rheodol (HLB 7.1; Kao Co., Ltd., Tokyo), 2 g Glycerol (Wako), $1 \mathrm{~m} l \mathrm{rNc}-\mathrm{p} 43(4.7 \mathrm{mg} / \mathrm{m} l)$, and $13 \mathrm{ml}$ HEBGP or distilled water for control immunogen. Trial and control immunogens were inoculated $0.2 \mathrm{~m} / /$ head intramuscularly in 33 mice, respectively. After that blood was collected from 3 mice were measured every week from 0 to 10 weeks post inoculation and $\mathrm{IgG}_{1}$ and $\operatorname{IgG}_{2 \mathrm{a}}$ antibodies were measured using the enzyme linked immunosorbent assay (ELISA) of Hohdatsu et al. [6] using rNc-p43 as antigen and anti-mouse $\operatorname{IgG}_{1}$ and $\operatorname{IgG}_{2 \mathrm{a}}$ rat monoclonal antibodies (Zymed Laboratories Inc., U.S.A.) as conjugates.

To determine the optimum time for measurement of IFN$\gamma$ and IL-4 in the mice inoculated with vegetable juice, a preliminary study was at first performed using $P$. acnes, which is known to induce macrophages [8]. Figure 1 depicts the serum IFN- $\gamma$ and IL-4 levels $0,2,4,6,8$, and 10 days after inoculation of the mice with $P$. acnes. The IFN- $\gamma$ levels peaked on the 6th and 8th day and decreased by day 10 , whereas the IL-4 levels remained similar on post inoculation day 4 and thereafter. Based on the results of the preliminary test, we measured IFN- $\gamma$ and IL- 4 on day 7 after inoculation of mice with vegetable juice.

Table 1 shows the serum IFN- $\gamma$ and IL- 4 levels and leukocyte counts on day 7 after inoculation of mice with vegetable juice. By the time of scheduled blood sample collection, all the mice that were inoculated with Jew's mallow, bitter gourd, gumbo, spinach, yam, and taro juices at lower dilution ratios than those shown had died. Thus, for these vegetable juices, the mice were inoculated with higher dilution ratios. The mice survived and assays could be performed, at dilution ratios of 4 for Jew's mallow, spinach, yam, and taro; at a dilution ratio of 8 for gumbo; and at a dilution ratio of 16 for bitter gourd.

IFN- $\gamma$ was below the limits of detection $(<10 \mathrm{pg} / \mu l)$ for

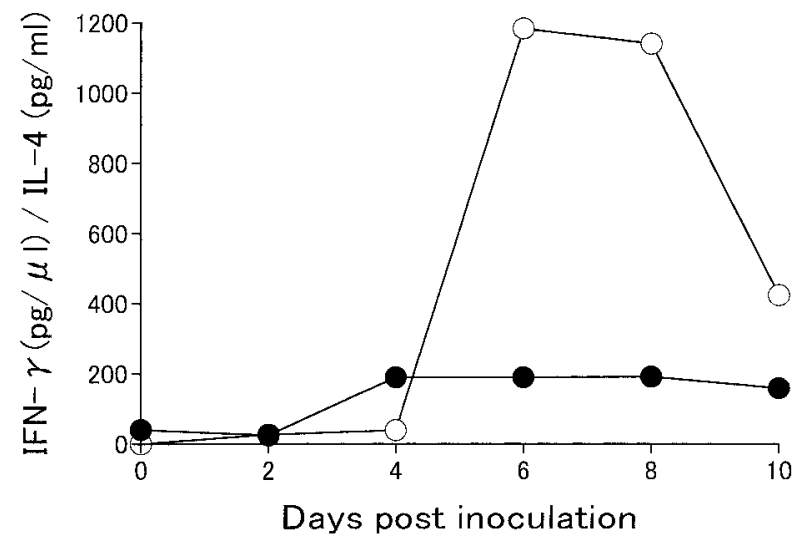

Fig. 1. Serum IFN- $\gamma$ and IL-4 levels of mice inoculated with Propionibacterium acnes. Each mouse was inoculated intraperitoneally with $0.5 \mathrm{~m} l$ of $P$. acnes suspension $(1 \mathrm{mg} / \mathrm{m} l)$. At 0 , $2,4,6,8$, and 10 days after inoculation, blood was collected from the hearts of 3 animals each. $\bigcirc$ : IFN- $\gamma$ and 0 : IL-4.

many vegetable juices, but in the mice inoculated with bitter gourd (Momordica charantia), there was marked induction of IFN- $\gamma$ (mean, $1,101 \mathrm{pg} / \mu \mathrm{l}$ ). A slight IFN- $\gamma$ induction, but not markedly high values, was also seen with carrots (167 $p \mathrm{~g} / \mu l)$, cauliflower $(102 \mathrm{gg} / \mu l)$, and water shield (137 $\mathrm{g} /$ $\mu l)$. However, IL-4 in the serum, as compared to the control group $(185 \mathrm{pg} / \mathrm{m} l)$, was not increased or decreased with any of the vegetable juices. Leukocyte counts were higher with several vegetable juices, including green pepper $(14,700 /$ $\mu l)$, water shield $(16,100 / \mu l)$, bitter gourd $(20,600 / \mu l)$, and yam $(15,000 / \mu l)$. No correlation was observed between leukocyte counts, IFN- $\gamma$ or IL-4.

Bitter gourd induced high titer of serum IFN- $\gamma$, so further testing was performed by inoculating mice separately with peel, pulp, and seed juices of bitter gourd. The IFN- $\gamma$ levels are shown in Table 2. All the mice inoculated with pulp juice at dilution ratios up to 1,280 died within 7 days after inoculation. However, pulp juice at dilution ratios of 2,560 and 5,120 induced higher levels of IFN- $\gamma$ than peel juice and seed juice at corresponding dilution ratios of 2,560 and 5,120 .

Immune responses in mice inoculated with trial and control immunogens are shown in Fig. 2. Serum $\operatorname{IgG}_{1}$ antibody titers against Nc-p43 of the mice inoculated with both immunogens rose at 2 weeks and peaked at 6-7 weeks post inoculation. The ELISA values of both groups were not significantly different. On the other hand, the serum $\operatorname{IgG}_{2 \mathrm{a}}$ antibody titer did not increase in the mice inoculated with control immunogen. $\operatorname{IgG}_{2 \mathrm{a}}$ antibody in the mice inoculated with trial immunogen began to increase on the 2 nd week and maintained a high level of antibodies until 9 weeks post inoculation. The antibodies in the mice with trial immunogen were higher than those with control immunogen.

Pharmacological research has shown that ingestion of a variety of food products can have antitumor effects by virtue of an increase in leukocytes and tumor necrosis factor-alpha 
Table 1. IFN- $\gamma$ and IL-4 levels and WBC counts of mice inoculated with various vegetable juices

\begin{tabular}{|c|c|c|c|c|}
\hline Vegetable & Dilution & $\begin{array}{c}\text { IFN- } \gamma \\
(p \mathrm{~g} / \mu l)\end{array}$ & $\begin{array}{c}\mathrm{IL}-4 \\
(\mathrm{pg} / \mathrm{m} l)\end{array}$ & $\begin{array}{l}\text { WBC } \\
(/ \mu l)\end{array}$ \\
\hline Eggplant & $\times 1$ & $<10$ & 164 & 3,700 \\
\hline Green pepper & $\times 1$ & $<10$ & 164 & 14,700 \\
\hline Tomato & $\times 1$ & $<10$ & 114 & 3,800 \\
\hline Pumpkin & $\times 1$ & $<10$ & 135 & 2,200 \\
\hline Watermelon & $\times 1$ & 15 & 256 & 10,300 \\
\hline Ginger & $\times 1$ & 15 & 214 & 11,300 \\
\hline Carrot & $\times 1$ & 167 & 101 & 11,300 \\
\hline Japanese radish & $\times 1$ & $<10$ & 142 & 7,800 \\
\hline Turnip & $\times 1$ & 27 & 126 & 7,000 \\
\hline Lotus root & $\times 1$ & 51 & 173 & 5,600 \\
\hline Burdock & $\times 1$ & $<10$ & 74 & 7,100 \\
\hline Irish potato & $\times 1$ & $<10$ & 81 & 8,000 \\
\hline Garlic & $\times 1$ & $<10$ & 82 & 10,300 \\
\hline Onion & $\times 1$ & $<10$ & 60 & 5,000 \\
\hline Green onion & $\times 1$ & $<10$ & 125 & 4,700 \\
\hline Leek & $\times 1$ & 15 & 82 & 3,500 \\
\hline Cabbage & $\times 1$ & 51 & 223 & 7,600 \\
\hline Komatsuna ${ }^{a}$ & $\times 1$ & $<10$ & 90 & 6,600 \\
\hline Napa cabbage & $\times 1$ & $<10$ & 72 & 8,600 \\
\hline Lettuce & $\times 1$ & $<10$ & 112 & 5,600 \\
\hline Broccoli & $\times 1$ & 15 & 98 & 9,400 \\
\hline Cauliflower & $\times 1$ & 102 & 95 & 10,800 \\
\hline Malabar spinach & $\times 1$ & 15 & 177 & 10,200 \\
\hline Angelica & $\times 1$ & 27 & 83 & 12,700 \\
\hline Jew's mallow nalta jute & $\times 4^{\mathrm{b})}$ & $<10$ & 174 & 9,600 \\
\hline Parsley & $\times 1$ & 75 & 159 & 7,600 \\
\hline Japanese ginger & $\times 1$ & 75 & 108 & 13,400 \\
\hline Water shield & $\times 1$ & 137 & 131 & 16,100 \\
\hline Celery & $\times 1$ & $<10$ & 95 & 9,500 \\
\hline Bitter gourd & $\times 16^{\mathrm{b})}$ & 1,101 & 290 & 20,600 \\
\hline Gumbo & $\times 8^{\mathrm{b})}$ & $<10$ & 87 & 10,800 \\
\hline Spinach & $\times 4^{\text {b) }}$ & 44 & 128 & 5,600 \\
\hline Yam & $\times 4^{\mathrm{b})}$ & 87 & 124 & 15,000 \\
\hline Taro & $\times 4^{\text {b) }}$ & 87 & 189 & 9,800 \\
\hline Control & & $<10$ & 185 & 3,500 \\
\hline
\end{tabular}

a) Komatsuna (Brassica campestris).

b) Mice did not die at dilution ratios of 4 for Jew's mallow, spinach, yam; at a dilution ratio of 8 for gumbo; and at a dilution ratio of 16 for bitter gourd.

Table 2. Induction of mouse IFN- $\gamma$ by peel, pulp, and seed juices of bitter gourd

\begin{tabular}{ccc}
\hline $\begin{array}{c}\text { Part of } \\
\text { Bitter gourd }\end{array}$ & Dilution $^{\text {a) }}$ & $\begin{array}{c}\text { IFN- } \gamma \\
(\mathrm{pg} / \mu l)\end{array}$ \\
\hline \multirow{3}{*}{ Peel } & $\times 1,280$ & 780 \\
& $\times 2,560$ & 590 \\
& $\times 5,120$ & 400 \\
\hline \multirow{3}{*}{ Pulp } & $\times 1,280$ & $\mathrm{~d}^{\mathrm{b})}$ \\
& $\times 2,560$ & 1,520 \\
& $\times 5,120$ & 1,640 \\
\hline \multirow{2}{*}{ Seed } & $\times 1,280$ & 500 \\
& $\times 2,560$ & 560 \\
& $\times 5,120$ & 340 \\
\hline
\end{tabular}

a) Dilution 1: $1,000 \mathrm{mg} / \mathrm{ml}$.

b) Mice died within 7 days post inoculation.
(TNF- $\alpha)[19,21]$. Vegetables that can markedly enhance macrophage production of TNF are cabbage, eggplant, Japanese radish, spinach, cucumbers, carrots, and onions [21]. This means that some of these vegetable extracts can be used to stimulate host immune responses [20]. In the present study, mice were inoculated intraperitoneally with 34 different types of vegetable juice, and IFN- $\gamma$ and IL-4 were measured as markers for induction of Th1 cells and Th2 cells, respectively. Serum IL-4 levels, as compared with the control group, were not markedly increased by any of the 34 vegetable juices. However, serum IFN- $\gamma$ levels were higher than the control group after inoculation with carrot, cauliflower, water shield, and bitter gourd juices. In particular, with bitter gourd ( $M$. charantia), even at a dilution ratio of 16, IFN- $\gamma$ was high at $1,101 \mathrm{pg} / \mu l$, showing very high IFN- $\gamma$ induction. Testing of the separate components of bitter gourd, peel, pulp, and seeds, showed that the pulp induced the highest levels of IFN- $\gamma$. Bitter gourd contains momordicin, a glucoside-like substance that can lower blood glucose [9]. Steroids extracted from charantin, a stigmasterol, are protein alkaloid complexes with insulin-like effects $[12,13]$. In addition, bitter gourd seeds have been shown to be effective in treatment of cancer [16]. Our results demonstrate that bitter gourd, especially its pulp, induced a high titer of IFN- $\gamma$ in mice, and shows promise as an immunostimulatory therapy specific to Th1 cells and IFN- $\gamma$ production [10].

Studies using the intracellular parasite Toxoplasma gondii have shown that administration of $T$. gondii immune serum alone is insufficient to prevent infection [18]. In addition, in Leishmania parasitic infections, the immune balance is skewed toward a Th2 response, with overproduction of IL-4 and inhibition of IFN- $\gamma$ induced macrophage activation. The Leishmania parasites phagocytized by macrophages are not digested, thus worsening infection $[2,3]$. This highlights the importance of Th1 cellular immunity in preventing intracellular parasitic infections. As demonstrated in our study, bitter gourd, especially its pulp juice, induced high levels of serum IFN- $\gamma$ which activates Th1 cellular immunity, which is essential for preventing intracellular parasitic infection.

The trial immunogen using HEBGP as immunopotentiator induced a high $\operatorname{IgG}_{2 \mathrm{a}}$ antibody in mice inoculated with it, and bitter gourd induced Th1 cellular immunity in mice inoculated with the trial immunogen. As heat extract of bitter gourd pulp produced these results, we consider the constituents of the heat extract are mainly carbohydrates.

The vegetables tested in our study are often eaten in a daily meals, and safety is generally not a concern with oral ingestion. However, mice died that were inoculated with Jew's mallow, bitter gourd, gumbo, spinach, yam, and taro juices. This requires further investigation of the active ingredients and characteristics of these vegetable juices. Deaths in mice inoculated with whole or pulp juices of bitter gourd occurred within 3 to 5 days after inoculation, thus raising the possibility of infection due to the immunocompromised condition induced by IFN- $\gamma$ overproduction, but it 

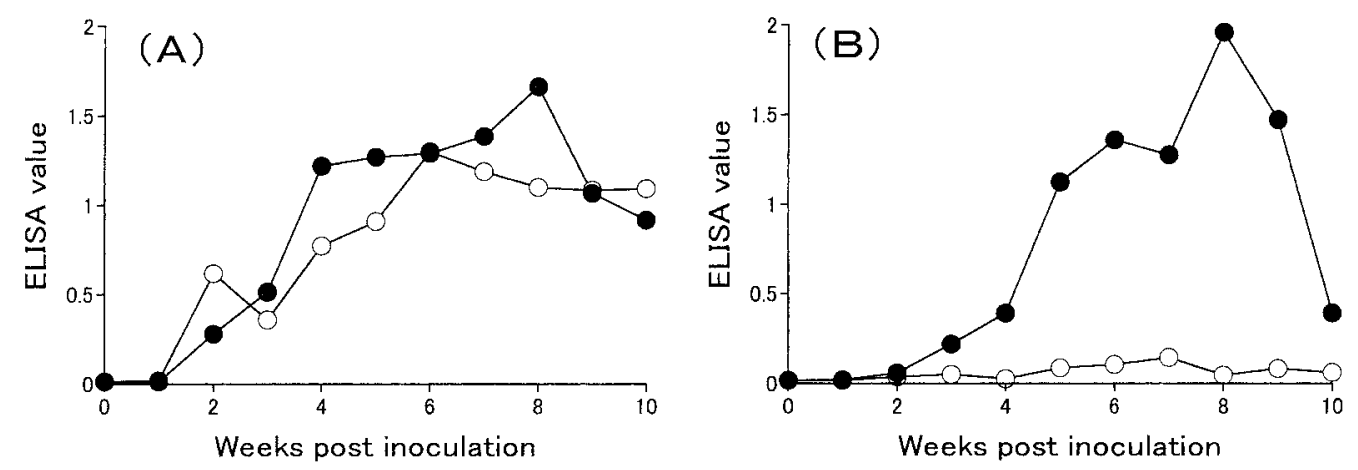

Fig. 2. Immune response against rNc-p43 in mice inoculated with trial and control immunogens, with and without the heat extract of bitter gourd pulp, respectively. Antibody titers were measured by ELISA using anti-mouse $\operatorname{IgG}_{1}$ and $\mathrm{IgG}_{2 \mathrm{a}}$ rat monoclonal antibodies. Each titer was the average value from 3 mice. (A) Mouse $\operatorname{IgG}_{1}$ antibody response. (B) Mouse $\mathrm{IgG}_{2 \mathrm{a}}$ antibody response. : Trial and $\mathrm{O}$ : Control immunogen groups.

is not clear. Further studies should be conducted to characterize the active ingredients of bitter gourd pulp that induce high IFN- $\gamma$ levels and to evaluate the ability of IFN- $\gamma$ induction as adjuvant therapy.

\section{REFERENCES}

1. Bloom, B. R., Modlin, R. L. and Salgame, P. 1992. Ann. Rev. Immunol. 10: 453-488.

2. Carvalho, E. M., Badaro, R., Reed, S. G., Jones, T. C. and Johnson, W. D. Jr. 1985. J. Clin. Invest. 76: 2066-2069.

3. Carvalho, E. M., Teixeira, R. S. and Johnson, W. D. Jr. 1981. Infect. Immun. 33: 498-500.

4. Dubey, J. P. and Lindsay, D. S. 1996. Vet. Parasitol. 67: 1-59.

5. Guler, M. L., Gorham, J. D., Hsieh, C. S., Mackey, A. J., Steen, R. G., Dietrich, W. F. and Murphy, K.M. 1996. Science 271: 984-987.

6. Hohdatsu, T., Eiguchi, Y., Ide, S., Baba, K. and Yamagishi, H. 1987. Vet. Microbiol. 13: 93-97.

7. Khan, I. A., Schwartzman, J. D., Fonseka, S. and Kasper, L. H. 1997. Exp. Parasitol. 85: 24-34.

8. MacVittie, T. J. 1979. RES J. Reticuloendothel. Soc. 26: 479490.

9. Marr, K. L., Mei, X. Y. and Bhattarai, N. K. 2004. Econ. Bot.
58: 435-455.

10. Morikawa, K., Kikuchi, Y., Abe, S., Yamazaki, M. and Mizuno, D. 1984. Gann 75: 370-378.

11. Moloy, K. J. and Powrie, F. 2001. Nat. Immunol. 2: 816-822.

12. Ng, T. B., Wong, C. M., Li, W. W. and Yeung, H. W. 1986. J. Ethnopharmacol. 15: 107-117.

13. Parkash, A., Ng, T. B. and So, W. W. 2002. J. Peptide Res. 59: 197-202.

14. Peterson, J. D., Herzenberg, L. A., Vasquez, K. and Waltenbaugh, C. 1998. Proc. Natl. Acad. Sci. U.S.A. 95: 3071-3076.

15. Sakaguchi, S. 2000. Cell 101: 455-458.

16. Singh, A., Singh, S. P. and Bamezai, R. 1998. Toxicol. Lett. 94: 37-46.

17. Son, E. S., Ahn, H. J., Kim, J. H., Kim, D. Y. and Nam, H. W. 2001. Korean J. Parasitol. 39: 241-246.

18. Stadtsbaeder, S., Nguyen, B. and Calvin-Preval, M. C. 1975. Ann. Immunol. 126C: 461-474.

19. Yamazaki, M. and Nishimura, T. 1992. Biosci. Biotech. Biochem. 56: 150-151.

20. Yamazaki, M. and Ueda, H. 2000. Jpn. J. Nutrition 58: 101108 (in Japanese).

21. Yamazaki, M., Ueda, H., Fukuda, K., Okamoto, M. and Yui, S. 1992. Biosci. Biotechnol. Biochem. 56: 149. 